\title{
ROZWÓJ METODY NARRACJI W WYCHOWANIU RELIGIJNYM DZIECI W POGLĄDACH POLSKICH PEDAGOGÓW
}

\author{
Developing the Method of Narrative in the Religious Education of \\ Children in the Views of Polish Pedagogues
}

Summary: The aim of the article is to present the development of the contemporary understanding of the modern narrative in religious education and in the gradual transition from stories and narratives to biographical narratives and those based on tradition. After first examining such aspects of the contemporary understanding of narrative as the catechetical method, they are then compared with the proposals of Fr. Zygmunt Bielawski (1877-1939) and Sr. Barbara Żulińska, CR (1881-1962).

Keywords: religious education, narrative, storytelling, verbal methods, observational method

\section{Wprowadzenie}

Źródłem katolickiego wychowania religijnego są Biblia, liturgia i Tradycja, które wymagają odpowiedniego sposobu przekazywania nauki w nich zawartych. Najczęściej stosowanymi metodami były i są te oparte na słowie - wykład, rozmowa, opowiadanie, pogadanki religijne, instrukcje i objaśnienia - którym towarzyszą metody oglądowe, takie jak obserwacja, pokaz, własny przykład². Rozwój nauk

\footnotetext{
${ }^{1}$ Dr Barbara Surma jest adiunktem w Katedrze Dydaktyki i Wczesnej Edukacji Dziecka na Wydziale Pedagogicznym Akademii Ignatianum w Krakowie. Adres: Akademia Ignatianum, ul. Kopernika 26, 31-501 Kraków; e-mail: barbara.surma@ignatianum.edu.pl

${ }^{2}$ Klasyfikacja metod podana za: Czesław Kupisiewicz, Podstawy dydaktyki ogólnej (Warszawa: PWN 1977), 153-178.
} 
humanistycznych i społecznych w sposób znaczący przyczynił się do wypracowywania nowych metod, które uwzględniają możliwości adresatów ich doświadczenia i przeżycia, ale też cele i treści wychowania religijnego zgodnego z nauczaniem Kościoła katolickiego. Analizując poglądy wybranych polskich pedagogów katolickich działających na przełomie XIX i XX wieku oraz współczesnych propozycji wykorzystania metody narracji w wychowaniu religijnym dziecka, można dostrzec pewien rozwój jej teoretycznego rozumienia i praktycznego zastosowania. Celem artykułu jest ukazanie procesu kształtowania się współczesnego rozumienia narracji $\mathrm{w}$ wychowaniu religijnym oraz stopniowego przechodzenia od metody opowiadania w propozycji Zygmunta Bielawskiego (1877-1939) oraz pogadanek Barbary Żulińskiej CR (1881-1962), przybliżających dzieciom treści biblijno-liturgiczne do opowiadania narracyjnego - biograficznego i nastawionego na przekaz tradycji.

\section{Współczesne podejście do narracji jako metody katechetycznej}

W ramach ruchu odnowy katechetycznej, rozwijającego się w XX wieku, podważono klasyczną praktykę katechetyczną dotyczącą podmiotu, doboru treści i metod. Zaakcentowano potrzebę uwzględnienia doświadczenia, aktywności i praktycznego sposobu uczenia się. Refleksja nad tradycyjnym przekazem prawd wiary (typu scholastycznego i doktrynalnego) oraz zwrócenie uwagi na potrzeby społeczeństwa przyczyniły się do stopniowego wprowadzania zmian na płaszczyźnie wychowania religijnego i otwarcia się na inne sposoby podejścia do poznania i doświadczenia ludzkiego, w tym religijnego. Stwierdzono, że narracja i narracyjność opowiadania poszerzają proces poznawczy o wymiar symboliczny ${ }^{3}$, dlatego należy wypracować nowe metody pracy z dziećmi i młodzieżą. Postulowane przez dydaktyków katechetycznych zasady „wierności Bogu” i „wierności człowiekowi” wpisują się w rozwój nowych metod.

Argumentami za uwzględnieniem kategorii narracji w szeroko rozumianej edukacji religijnej są: cel, treść, źródła doboru treści, język biblijny i liturgiczny, proceduralny sposób nabywania wiedzy oraz właściwości podmiotu poznającego. Z jednej strony są one nie tylko wynikiem zmiany paradygmatów wypracowanych na gruncie filozofii i psychologii poznawczej, ale także rozwoju teologii narracyjnej i zastosowania krytyki narracyjnej w egzegezie.

Z drugiej są rezultatem refleksji współczesnej katechetyki nad potrzebą udzielenia i uaktualnienia odpowiedzi na najistotniejsze pytania, jakie stawia sobie człowiek w czasach dynamicznych przemian społeczno-kulturowych

${ }^{3}$ Enzo Biemmi, „Narracyjny wymiar katechezy”, w: Narracyjny wymiar edukacji chrześcijańskiej, red. Anna Królikowska (Kraków: Akademia Ignatianum, Wydawnictwo WAM 2012), 19. 
w świetle Objawienia Bożego. Kwestie, które go interesują, dotyczą jego własnej egzystencji, sensu życia, codziennych problemów, tożsamości, godności osobistej, szacunku do siebie i do drugiego człowieka, wolności, rozumienia siebie i rzeczywistości, w której się znajduje, czyli tego, co składa się na jego zewnętrzny i wewnętrzny świat.

Narracja jest zapisem zrozumienia opowiadanej historii lub inaczej reprezentacją poznawczą zdarzeń z przeszłości przechowywanych w pamięci. Przekazywana treść może być rekonstruowaniem ze śladów pamięciowych wydarzeń, które mogą pomóc w zrozumieniu aktualnej sytuacji ${ }^{4}$. Narracja jako narzędzie katechetyczne może pomóc we wzbudzaniu zainteresowania i włączania jej odbiorców w katechezę. Ważne są tu pedagogiczny i dydaktyczny aspekt komunikacji wiary i forma jej przekazu. Rozwijanie poznania wiary nie wymaga dialektyki i wypracowanych przez nią argumentów, ale raczej świadectwa, czyli powrotu do źródłowych form głoszenia orędzia zbawczego ${ }^{5}$. To świadectwo może wiązać się z narracją biograficzną, kiedy nauczyciel lub uczeń opowiada o swoim doświadczeniu Boga, albo z narracją nastawioną na tradycję, kiedy zgłębia się treści orędzia zbawczego. Jest ona zawarta w Piśmie Świętym, w księdze wiary, zawierającej opowiadania o szczególnych wydarzeniach, w których Bóg objawia swoją obecność człowiekowi, oraz w Credo, symbolu wiary, będącym jej doktrynalną formułą.

Struktura narracyjna Credo opiera się na trzech etapach historii zbawienia związanych z przeszłością, teraźniejszością i przyszłością. Pierwszy etap to stworzenie, początek historii zbawienia, a drugi to odkupienie, które stanowi o teraźniejszości. Trzeci wskazuje na przyszłość, jest oczekiwaniem na powtórne przyjście Mesjasza. A zatem Credo zawiera opowiadanie o Bogu Ojcu stworzycielu, Synu, który umarł i zmartwychwstał i który daje początek nowemu stworzeniu i prowadzi do wypełnienia dzieła Bożego. Historia ta jest narracją przekazującą dzieje człowieka, z którym Bóg nawiązuje przymierze. Narracją opartą nie na intelektualnych spekulacjach, ale na doświadczeniu działania Boga Trójjedynego w historii człowieka ${ }^{6}$, opowiedzianej przede wszystkim na kartach Pisma Świętego. Wymiar narracyjny Biblii i Credo, a tym samym wiary chrześcijańskiej, implikuje sposób jej komunikowania. Opowiadanie biblijne ponadto zamyka w sobie pamięć minionych wydarzeń, czyni je możliwymi aktualnie (liturgia i modlitwa), otwierając dojście do ewentualnego spotkania z Bogiem, który jest nadal obecny w dziejach ludzkości. W edukacji religijnej od zawsze przekazywana była ta historia w sposób obrazowy oraz słowny. Współcześnie dąży się, by słuchacz miał możliwość bezpośredniego kontaktu z tekstem. Zauważa się, że struktura

\footnotetext{
${ }^{4}$ Por. Jerzy Trzebiński, „Autonarracje nadają kształt życiu ludzkiemu”, w: Narracja jako sposób rozumienia świata, red. Jerzy Trzebiński (Gdańsk: GWP 2002), 22-24.

${ }^{5}$ Por. Biemmi, Narracyjny wymiar katechezy, 16.

${ }^{6}$ Por. tamże, 15.
} 
narracyjna opowiadania formuje odbiorcę i pozwala mu podążać za śladami dzieł Boga, które prowadzą do odkrycia Jego obecności w historii zbawienia.

Model strategii oddziaływania na czytelnika składa się z pięciu punktów, według których można dobrać i analizować tekst podczas katechezy. Są to: (1) sytuacja początkowa - zawierająca informacje początkowe; (2) komplikacja, która ukazuje trudności, jakie ma bohater opowiadania do pokonania; (3) działanie transformujące, które zawiera pokonanie trudności; (4) rozwiązanie, które ogłasza ustanowienie warunków poprzedzających trudności; (5) sytuacja końcowa, która objaśnia rozpoznanie nowego osiągniętego wymagania.

Narracja jako próba zrozumienia losu człowieka, odwołująca się do filozoficznych przesłanek opowieści (mythos i mimesis) ma strukturę czasową, modelującą rzeczywistość jako scenę, w której występuje określony bohater ze swoimi intencjami, napotykający na trudności w ich realizacji, a trudności te w wyniku zdarzeń, toczących się wokół zagrożonych intencji zostają przezwyciężone (bądź nie). Przedstawiane wydarzenia i czyny bohatera są logicznie powiązane, wewnętrznie koherencyjne i mają określony sens ${ }^{7}$. Na schemat narracyjny odwołujący się do wyżej opisanej struktury intrygi składają się cztery komponenty tworzące poznawcze przesłanki możliwych fabuł historii w ramach konkretnej sfery życia jednostki, tak jak ona je rozumie i interpretuje. Człowiek zatem dostrzega przestrzeń, w której pojawiają się bohaterowie (pierwszy komponent) podlegający pewnym wydarzeniom wraz ze swoimi intencjami, planami, wartościami (drugi komponent). $\mathrm{W}$ trakcie dążenia do urzeczywistniania swoich zamiarów bohaterowie napotykają różnego rodzaju komplikacje (trzeci komponent), które wymagają nakreślenia uwarunkowań i szans przezwyciężania pojawiających się trudności i realizacji ich planów (czwarty komponent). Uaktywnienie schematu poznawczego, podczas którego jednostka kategoryzuje i integruje oczekiwane treści oraz podsuwane reguły interpretacyjne, tworząc historię (obraz), prowadzi do narracyjnego konstruowania rzeczywistości przez umysł jednostki.

Proponowana we współczesnej katechezie narracja wywodzi się z mimetycznej koncepcji literatury oraz krytyki narracyjnej opracowanej na gruncie teologii biblijnej. Metoda ta dopiero się rozwija ${ }^{8}$, nadal zachodzi potrzeba opracowywania nowych, praktycznych rozwiązań w interpretowaniu tekstów biblijnych? Krytyka narracyjna mimo dostrzeżenia w niej katechetycznego waloru, jakim jest możliwość stosowania jej zarówno przez początkującego czytelnika, jak i przez specjalistę, nie wydaje się na tyle znana, by mogła być stosowana na szeroką skalę

Błażej Baszczak, „Tożsamość człowieka a pojęcie narracji”, Analiza i Egzystencja 4 (2011): 125.

${ }^{8}$ Zob. Stefan Szymik, „Metoda narracyjna jako propozycja dialogu z tekstem”, w: Język Biblii. Od stuchania do rozumienia, red. Wojciech Pikor (Kielce: Verbum 2005), 11-20 oraz Henryk Witczyk, „Czytelnik jako współ-kreator postaci”, w: Język Biblii.

${ }_{9}$ Przykład interpretacji tekstów biblijnych w kluczu krytyki narracyjnej opracował na przykład Zdzisław Pawłowski, Narracja i egzystencja. Genesis w hermeneutyce opowieści (Toruń: Wydawnictwo Naukowe UMK 2013). 
w edukacji religijnej. Wymaga również od odbiorcy pewnych umiejętności, dlatego w proponowanej formie nie może być stosowana na każdym etapie nauczania. Należy jednak odnotować kilka istotnych i uniwersalnych elementów, którymi można się kierować, próbując wprowadzać metodę narracji do katechezy. Można je traktować jako podstawę do dalszych działań edukacyjnych.

Pierwszym elementem jest zwrócenie uwagi na wywołanie zaangażowania czytelnika w bezpośrednim kontakcie z opowiadaniem biblijnym, wynikające z współzależności między tekstem a jego przeżyciami. Jest to spotkanie dwóch rzeczywistości, przy czym tekst narracyjny stawia czytelnika $\mathrm{w}$ konfrontacji z jego problemami egzystencjalnymi. Odwołuje się do złożoności człowieka, dostrzegając jego wielkość, ale też słabości i sprzeczności występujące w jego życiu osobistym, rodzinnym, społecznym i politycznym. Drugim elementem jest zaproszenie czytelnika do przyjęcia postawy empatii (lub odrzucenia) w stosunku do postaci opowiadania, wydawania oceny etycznej dotyczącej swojego działania; wyobrażania sobie nowych sposobów przeżywania własnego życia; odkrywania nowej tożsamości. To zaangażowanie polega na odczytywaniu tekstu w nowej perspektywie prowadzącej do zmiany, przemiany i nowego życia (bądź nie, w imię wolności danej człowiekowi ${ }^{10}$.

Trzecim elementem jest aktywne wprowadzenie w historię Boga i człowieka, która trwa i uaktualnia się "tu i teraz”. Bóg objawiający się w historii, w konkretnych wydarzeniach, zaprasza człowieka do nawiązania z Nim relacji, zawarcia przymierza. Kolejnym elementem jest język źródeł doboru treści nauczania katechetycznego i to, co można nazwać wychowaniem do lektury znaków/symboli ${ }^{11}$.

Rozwijanie poznania wiary w wymiarze narracyjnym, rozumiane jako świadectwo wiary, może być realizowane w trzech etapach. Pierwszy etap to głoszenie-opowiadanie (traditio) o najważniejszym wydarzeniu historii zbawienia - Paschy (tajemnica wiary: Jezus umarł, zmartwychwstał, powróci), drugi to przyjęcie, które wyrażane jest w autonarracji, czyli opowiadanie, w jaki sposób to wydarzenie przemieniło życie osoby głoszącej (receptio) i trzeci - wyznanie wiary jako odpowiedź i świadectwo wiary $(\text { redditio })^{12}$.

Dawanie świadectwa najczęściej odnosi się do zadań czy roli katechety, który ma być prawdziwym świadkiem tego, co głosi. W narracyjnym ujęciu jego zadaniem jest natomiast umożliwienie katechizowanym spotkania ze słowem Bożym i stworzenie im odpowiednich warunków do autonarracji, narracji biograficznej. W tym znaczeniu opowiadanie o własnym życiu duchowym stanowi integralną

${ }_{10}$ Augusto Barbi, „Analiza narracyjna i przemieniająca moc opowiadania”, w: Narracyjny wymiar, 65.

${ }^{11}$ Zob. Barbara Surma, „Język biblijny - etapy wprowadzania dzieci do odczytywania znaków", w: Język oknem na świat - edukacja językowa w pedagogice Marii Montessori, red. Małgorzata Miksza (Łódź: Palatum 2015), 99-115.

12 Enzo Biemmi, La catechesi di iniziazione cristiana dei fanciulli e dei ragazzi: itinerari differenziati e catechismi CEI, www.parocchie.it (dostęp: 20.01.2015). 
część procesu wzajemnego przekazywania wiary. Możliwość ujęcia w opowiadaniu własnej historii życia włącza katechizowanego w narrację historii zbawienia, przez wzbudzenie osobistego zaangażowania doprowadza do udzielenia odpowiedzi na otrzymany dar wiary ${ }^{13}$.

\section{Narracja biograficzna i nastawiona na tradycję}

Współcześnie narracja jako metoda katechetyczna przybiera formę opowiadania dialogicznego, które prowadzi do dwubiegunowego procesu uczenia się, zachodzącego między uczniem a przedmiotem uczenia się. W związku z tym narracja z jednej strony może opierać się na uczniach lub ich doświadczeniach, z drugiej na przekazywanych historiach biblijnych i historii chrześcijaństwa. Istotne jest, by opowiadania odnosiły się do sytuacji znanych słuchaczom oraz działań, które mogą mieć jakieś znaczenie dla życia dziecka. Źródłem opowiadań są sytuacje egzystencjalne, które stymulują rozwój tożsamości. Słuchacza podprowadza się, by mógł dokonać wyboru, który ma wymiar moralny.

Wyodrębnia się narrację biograficzną - opowiadanie o sobie samym, które to pozwala na uświadomienie przeżyć, ich komunikację, rozwój tożsamości, otwieranie się na własne doświadczenie, jego ocenę oraz na udzielenie sobie odpowiedzi na pytania, jakie konsekwencje się poniosło i jak sobie z nimi radzić. Jest to refleksja dotycząca aktualnej sytuacji, ale na tle dotychczasowych wydarzeń i wyborów, prowadząca do wyznaczenia celów na przyszłość.

Natomiast narracja zorientowana na tradycję jest przekazem opowiadań kulturowych, tekstów, które służą rozumieniu celów i wartości ludzkiego działania. Narracja taka poszerza modele postrzegania i interpretacji oraz stymuluje rozwój indywidualnej i społecznej tożsamości. Wymienia się pięć koncepcji narracji biblijnych: (1) opowiadania jako przedstawienie historycznej prawdy, na przykład o działaniu Boga; (2) opowiadania jako wzorcowe przekazanie doktryny; (3) zinterpretowane opowiadanie - pozwala na ustalanie związków z doświadczeniami codziennego życia; (4) narracja dialogiczna - wskazuje się w tekście coś zaskakującego i dzięki temu zaprasza się słuchacza do pochylenia się nad istotą przekazu w nim zawartą; (5) narracja jako środek integrowania własnego doświadczenia korelacja między tekstem biblijnym a codziennymi doświadczeniami przeszłości $^{14}$. Pierwsze dwa mają charakter zamknięty, w pewnym sensie nie pozwalają na dialog, gdyż nastawione są na przekaz $\mathrm{w}$ formie opowiadania. Pozostałe trzy odnoszą się do możliwości słuchacza-odbiorcy, nawiązują do sytuacji egzystencjalnych i do jego obecnej sytuacji w świetle treści orędzia zbawczego.

${ }^{13}$ Propozycje pracy z tekstem oraz metody analizy tekstów narracyjnych przedstawiają: Jan Kochel, Zbigniew Marek, Pedagogia biblijna w katechezie (Kraków: Wydawnictwo WAM 2012).

${ }^{14}$ Monika Scheidler, „Narracja biograficzna i narracja zorientowana na tradycję jako podstawowe formy nauczania katechetycznego", w: Narracyjny wymiar, 106-107. 
Narracja biograficzna i ta nastawiona na tradycję mają wspólny cel, jakim jest połączenie życiowych doświadczeń dzisiejszych uczniów z tradycją biblijno-chrześcijańską. Ma to wymiar antropologiczny, którego początki w wychowaniu religijnym datuje się na drugą połowę XX wieku.

Po krótkim zaprezentowaniu najważniejszych aspektów współczesnego rozumienia narracji jako metody katechetycznej sięgnijmy do wcześniejszych metod wychowania religijnego, które były stosowane w Polsce na początku ubiegłego wieku w celu ukazania ich rozwoju.

\section{Wykład - opowiadanie w propozycji ks. Zygmunta Bielawskiego}

W XIX wieku panował ruch neoscholastyczny, który proponował „metodę objaśniania tekstów katechizmowych, zwaną metodą egzegetyczną czy dedukcyjną oraz metodę pamięciowego przyswajania sobie wyjaśnianych tekstów ${ }^{15}$. Katecheci posługiwali się między innymi katechizmem Józefa Deharbe’a z roku 1847, zawierającym pytania i odpowiedzi, a przebieg nauczania miał trzy stopnie: lectio (czytanie), explicatio (wyjaśnienie), aplicatio (zastosowanie). W 1905 roku Pius X wydaje tak zwany Mały katechizm składający się z 433 pytań i odpowiedzi. Było to kompendium wiedzy, którą przekazywano na katechezie w celu ich zapamiętania.

Na początku XX wieku podejmowano dyskusje na temat relacji między katechezą a treściami katechizmu. W Polsce dominowały dwie tendencje. Jak pisze Andrzej Kiciński:

Pierwsza podporządkowywała całą katechezę katechizmowi (W. Gadowski). Druga tendencja ograniczała treść katechizmu do minimum i przydzielała mu jedynie miejsce na końcu katechezy, jako jej streszczenie. Prawdę katechizmową wyprowadzano z materiału poglądowego przez indukcję. Była to tendencja zgodna z psychologiczną zasadą, że najtrwalej przyjmowana i zapamiętywana jest prawda podawana w kontekście życiowym, gdyż zaciekawia, porusza uczucia oraz pobudza wolę do działania. Przedstawicielem tej drugiej tendencji był Z. Bielawski. Znalazła ona wyraz w Małym katechizmie rzymskokatolickim (Lwów 1927), w którym autor ukazuje prawdy wiary w formie prostych, przystępnych opowiadań, a pytania katechizmowe (zaledwie 46) pojawiają się jako ich podsumowanie. Nawet podstawowe modlitwy Ojcze nasz, Zdrowaś Maryjo opatrzone są prostą interpretacją (parafrazą); dzięki temu katechizm zmienia ujęcie z przedmiotowego na zdecydowanie podmiotowe ${ }^{16}$.

${ }^{15}$ Władysław Kubik, Rozwój myśli dydaktycznej w polskiej literaturze katechetycznej w latach 1895-1970 (Warszawa: Akademia Teologii Katolickiej 1987), 35.

16 Andrzej Kiciński, „Kierunki rozwoju katechizmów katolickich”, Roczniki Pastoralno-Katechetyczne 4 (2012), 130, https://www.kul.pl/files/816/public/2012/AK.pdf (dostęp: 30.03.2017). 
Ks. Bielawski opierał uczenie na procesie przekazywania pojęć religijnych i kształcenia woli ${ }^{17}$. Przyjmował za Ottonem Willmanem trzy stopnie przyswajania pojęć ze strony dziecka: (1) uchwycenie (przyjęcie treści i zatrzymanie jej); (2) zrozumienie; (3) przerobienie. W praktyce ks. Bielawski ustalił trzy stopnie psychologiczne przyswajania pojęć - wykład, wyjaśnienie, zastosowanie, na które składały się podstopnie.

Przyjęcie treści religijnych wymagało jego zdaniem przygotowania i zapowiedzenia tematu, na przykład: „Moje dzieci każde z was chciałoby z pewnością dostać się do nieba. Co musicie czynić, abyście się dostały do nieba?"18. Później następował przekaz prawd przy zastosowaniu metody opowiadania było to przybliżenie własnymi słowami wybranego tekstu biblijnego z tekstem, na przykład: „Bóg daje dziesięć przykazań na górze Synaj”. Opowiadanie to miało na celu wyprowadzenie pojęć religijno-moralnych i ich wyjaśnienie (abstrahowanie pojęcia z poglądu, zebranie cech istotnych - definicja, uogólnienie pojęcia, tworzenie pojęć pewnych, koncentracja logiczna - łączenie nowego pojęcia z pojęciami pokrewnymi). Opowiadanie było przeplatane pytaniami utrwalającymi oraz towarzyszyły mu obrazy ilustrujące istotne sceny dla wygłaszanego poglądu.

Ostatnim stopniem było zastosowanie - wartościowanie prawd religijnych i zasad religijno-moralnych, które polegało na konkretyzowaniu, a więc odnoszeniu usłyszanych prawd do obecnej sytuacji i do życia wychowanka, motywowanie i naprowadzanie dziecka do podjęcia decyzji i postanowienia, by daną prawdę czy zasadę wprowadzić w życie. Na końcu podawano definicje z Małego katechizmu do zapamiętania. Była to próba wyjaśnienia przekazywanych prawd wiary i zaangażowania słuchacza poprzez pytania i opowiadanie.

Bielawski uważał, że „nauczanie nie jest biernym przyjmowaniem treści wiedzy, lecz organicznym i planowo ułożonym narastaniem wiadomości

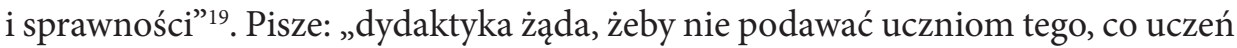
sam zdobyć może”20. Niemniej: „zdobycie samodzielne prowadzi jedynie do intensywnego i jasnego uchwycenia prawdy, nie umożliwia jednak ani przeżyć religijnych, ani wartościowania prawdy. Stąd musi się w nauce religii używać i formy wykładowej, i form rozwijających"21.

Dostrzegając słabe strony wykładu, proponował metody rozwijające i heurystyczno-erotematyczne (pytanie nauczyciela i ucznia, odpowiedzi ucznia),

17 Zob. więcej na temat poglądów wychowawczych ks. Z. Bielawskiego: Janina Kostkiewicz, Kierunki i koncepcje pedagogiki katolickiej w Polsce 1918-1939 (Kraków: Oficyna Wydawnicza „Impuls” 2013).

18 Zob. Przygotowanie do spowiedzi i Komunji św., oprac. Zygmunt Bielawski (Kraków: Nakładem Zgromadzenia ks. ks. Misjonarzy [Kleparz 19] 1922), 4-7.

19 Zygmunt Bielawski, Pedagogika religijno-moralna (Katechetyka) (Lwów: Nakładem Towarzystwa „Bibljoteka Religijna” im. X. Arcyb. Bilczewskiego 1934), 375-376.

20 Tamże, 385.

21 Tamże. 
wypracowania pisemne, rysunek katechety, pieśń religijną. W treściach odwołuje się do nauki historii biblijnej, którą katecheta miał przekazać w formie wykładu-opowiadania ${ }^{22}$ przedstawionego $\mathrm{w}$ sposób szczegółowy i barwny. Teksty biblijne miały być wplatane $\mathrm{w}$ treść opowiadania i przytaczane dosłownie, ale nie były osobno wyodrębniane i czytane $\mathrm{w}$ całości $\mathrm{i}^{23}$. Jego propozycje katechez były dostosowywane do wieku adresatów, zwracał on szczególną uwagę na potrzebę indywidualizacji i korelacji. Można stwierdzić, że odwołując się do postulatów psychologii, personalizmu pedagogicznego i pedagogiki wartości, Bielawski próbował przełamać sztywne traktowanie teorii stopni formalnych. Metoda wykładu była opowiadaniem, w którym przez zadawanie pytań aktywizowano uczniów do myślenia i samodzielnego poszukiwania prawd wiary ${ }^{24}$.

Porównując z pięcioma koncepcjami metody narracji, propozycje ks. Bielawskiego można nazwać opowiadaniami ukierunkowanymi na przekaz doktryny z próbą uaktywnienia słuchacza i wyjaśnienia mu historii zbawienia zapisanego na kartach Biblii. Tematyka katechez ma układ teocentryczny.

\section{Pogadanki - rozmówki w wychowaniu religijnym dzieci przedszkolnych w poglądach s. dr Barbary Żulińskiej}

Siostra Barbara Żulińska ${ }^{25}$ zajmowała się przede wszystkim wychowaniem dzieci $\mathrm{w}$ wieku przedszkolnym, dlatego jej propozycje mają inny niż u ks. Bielawskiego charakter. Uważała, że wychowanie dziecka należy oprzeć na metodach naukowych, ale wychodząc „od zrozumienia duszy dziecka i jej rozwoju”26. Postulowała zatem, by na poziomie wychowania przedszkolnego dążyć do zjednoczenia dziecka z Bogiem, a nauczanie religii rozpocząć w szkole. Słusznie zauważa, że ważne jest stworzenie odpowiedniej atmosfery, zarówno związanej z materialnym wyposażeniem sal, jak i z postawą i zachowaniem nauczycielki pracującej w ochronce. Twierdziła również, że "pierwszym katechizmem dzieci ma być przyroda”, gdyż dziecko pojmuje Boga w Jego dziełach, porównywała to do procesu poznania Boga-Stwórcy przez człowieka. Tłumaczy to tym, że dziecko poznaje najpierw to, co podpada pod zmysły, ale należy przez pogadanki wskazywać mu, że to wszystko pochodzi od Boga. Zaleca także, by opowiadania ze Starego Testamentu nie

22 Bielawski proponuje metodę wykładu, która jednak z punktu nowoczesnej dydaktyki jest raczej pewną formą organizacyjną niż metodą. W związku z tym w ramach wykładu podaje inne metody słowne i oglądowe.

23 Zob. Zygmunt Bielawski, Dzieje biblijne Starego i Nowego Przymierza (Kraków: Nakładem Kurii Metropolitalnej w Krakowie 1959) oraz tenże, Historia biblijna Starego i Nowego Testamentu (Opole: Wydawnictwo św. Krzyża w Opolu 1961).

24 Por. Kubik, Rozwój myśli.

25 Zob. więcej o Żulińskiej: Kostkiewicz, Kierunki i koncepcje.

${ }^{26}$ Barbara Żulińska CR, O wychowaniu religijnem dzieci w wieku przedszkolnym (PoznańWarszawa-Wilno-Lublin: Nakład Księgarni św. Wojciecha 1931), 1.

27 Tamże, 6. 
przekazywać dziecku w wieku przedszkolnym, jego umysł bowiem nie zrozumie jego walorów. Postuluje zatem, aby wychodzić od Nowego Testamentu i osoby Chrystusa $^{28}$, ale również zwraca uwagę na „zdolności dzieci i przejawy duszy dziecka, które w jego wieku wysuwają się na plan pierwszy"29.

Wykorzystując wyobraźnię dziecka, proponuje pogadanki, którym towarzyszyły obrazy (gotowe, ruchome, plastyczne, świetlne, zdjęcia, sztuka). Ich znaczenie tłumaczyła potrzebą doświadczania przez dziecko zmysłami. Ważną rolę w życiu religijnym odgrywały uczucia, dlatego metoda miała być „interesująca i plastyczna, by dziecko wżyło się w słyszane opowiadanie, a przez to współczuło z osobami występującymi” ${ }^{30}$. Ponieważ refleksja następuje później, należy jej zdaniem pobudzać dziecko do myślenia. Pogadanki zatem obejmują opowiadanie, rozmowę i pytania połączone $\mathrm{z}$ metodą oglądową. Oprócz treści nastawionych na opowiadania $\mathrm{z}$ życia Chrystusa i świętych występują też te wprowadzające dzieci w liturgię $e^{31}$. Rozmówki te ułożone zgodnie z rokiem liturgicznym przeplatane są pytaniami, pieśniami, modlitwami, wierszykami, aktywnością plastyczną dzieci i mają charakter przekazu zasad moralnych. Istotne jest to, że rozmówki te opierają się na bezpośrednim doświadczeniu dzieci i poznaniu zmysłami. Przykładem takich zajęć jest wyjaśnienie dzieciom znaczenia gestu posypania popiołem głów w Środę Popielcową. Po pierwsze, dzieciom pokazuje się popiół, palmę, krzyż i fioletową bibułkę, która służy do wykonania kwiatów, po drugie, należy się odwołać do ich przeżyć. Zajęcia planowane są na czwartek tuż po Środzie Popielcowej. Przez pytania typu: kto z was był wczoraj w kościele? co robił ksiądz? może ktoś z was wie, dlaczego właśnie wczoraj posypywano głowy? - nauczyciel wprowadza dzieci w zagadnienie przeżywania Wielkiego Postu, ale ściśle odwołującego się do doświadczeń dzieci. Następnie przez przytoczenie opowiadania o dzieciach w pewnej ochronce, które podjęły się określonych wyrzeczeń, proponuje wychowankom również podjęcie podobnego postanowienia.

Jest to przykład opowiadania, które można określić początkiem tworzenia się metody narracyjnej, występujący w niej bohaterowie są wzorem do naśladowania, a także inspirują do refleksji i odniesienia do własnej biografii. W pogadankach dla dzieci nie przytacza się tekstów biblijnych, są one przybliżane przez opowiadanie (parafrazowanie tekstu) oraz ilustrowane obrazami, figurami.

28 Tamże, 7.

29 Tamże, 8.

30 Tamże, 13.

31 Barbara Żulińska, Liturgia w ochronie. Rozmówki z małymi dziećmi (Katowice: Nakł. Księgarni św. Jacka w Katowicach 1946). 


\section{Podsumowanie}

Analizując propozycje katechez opracowanych przez ks. Bielawskiego i s. Żulińską, można stwierdzić, że źródłem nauczania były: Biblia, liturgia i Tradycja. Cele przekazu stanowiło przybliżenie historii zbawienia, nauczania biblijnego i katechetycznego, które miało prowadzić do zapamiętania prawd wiary (ks. Bielawski) i kształtowania woli (wychowanie moralne) oraz nawiązania relacji z Bogiem (s. Żulińska). Zarówno metoda wykładu, jak i opowiadań miała prowadzić do zrozumienia, przyswojenia i realizacji usłyszanych prawd w życiu wychowanka. Połączenie metod słownych z oglądowymi wynikało z obserwacji dzieci i ich rozwoju. Rozumiano również, że sytuacje egzystencjalne, bliskie i znane wychowankom, są ważne w pracy wychowawczej, dlatego i pytania stawiane przez ks. Bielawskiego, i opowiadania „biograficzne” s. Żulińskiej nawiązywały do doświadczeń dzieci.

Brakuje w nich jednak możliwości bezpośredniego kontaktu z tekstami biblijnymi, które mogłyby przemawiać do słuchacza wprost. Opowiadania odwołujące się do Pisma Świętego wybierane były raczej w celu uzasadnienia i wyjaśnienia prawd doktrynalnych (na koniec katechezy dzieci miały podane pytanie i odpowiedź do zapamiętania lub zasadę, jak postępować), a nie narracji dialogicznej. Porównując te propozycje ze współczesnym rozumieniem narracji, widać postęp w podejściu zarówno do rozumienia przesłania biblijno-liturgicznego, jak i wychowania religijnego, które ma prowadzić do osobowej relacji z Jezusem.

Streszczenie: Celem artykułu jest ukazanie procesu kształtowania się współczesnego rozumienia narracji w wychowaniu religijnym oraz stopniowego przechodzenia od metody wykładu (opowiadania) i pogadanek do narracji biograficznej i nastawionej na przekaz tradycji. Po przybliżeniu wybranych aspektów współczesnego rozumienia narracji jako metody katechetycznej porównano je z propozycjami ks. Zygmunta Bielawskiego (1877-1939) oraz s. dr Barbary Żulińskiej CR (1881-1962).

Słowa kluczowe: wychowanie religijne, narracja, opowiadanie, metoda obserwacji, metody słowne

\section{Bibliografia}

Barbi, Augusto. „Analiza narracyjna i przemieniająca moc opowiadania”. W: Narracyjny wymiar edukacji chrześcijańskiej, red. Anna Królikowska, 41-68. Kraków: Akademia Ignatianum, Wydawnictwo WAM, 2012.

Baszczak, Błażej. „Tożsamość człowieka a pojęcie narracji”. Analiza i Egzystencja 4 (2011): 123-140. Bielawski, Zygmunt. Dzieje biblijne Starego i Nowego Przymierza. Kraków: Nakładem Kurii Metropolitalnej w Krakowie, 1959.

Bielawski, Zygmunt. Historia biblijna Starego i Nowego Testamentu. Opole: Wydawnictwo św. Krzyża w Opolu, 1961. 
Bielawski, Zygmunt. Pedagogika religijno-moralna (Katechetyka). Lwów: Nakładem Towarzystwa „Bibljoteka Religijna” im. X. Arcyb. Bilczewskiego, 1934.

Biemmi, Enzo. La catechesi di iniziazione cristiana dei fanciulli e dei ragazzi: itinerari differenziati e catechismi CEI, www.parocchie.it (dostęp: 20.01.2015).

Biemmi, Enzo. „Narracyjny wymiar katechezy”. W: Narracyjny wymiar edukacji chrześcijańskiej, red. Anna Królikowska, 13-24. Kraków: Akademia Ignatianum, Wydawnictwo WAM, 2012.

Kiciński, Andrzej. „Kierunki rozwoju katechizmów katolickich”. Roczniki Pastoralno-Katechetyczne 4 (2012): 117-138, https://www.kul.pl/files/816/public/2012/AK.pdf (dostęp: 30.03.2017).

Kochel, Jan, Zbigniew Marek. Pedagogia biblijna w katechezie. Kraków: Wydawnictwo WAM, 2012.

Kostkiewicz, Janina. Kierunki i koncepcje pedagogiki katolickiej w Polsce 1918-1939. Kraków: Oficyna Wydawnicza „Impuls”, 2013.

Kubik, Władysław. Rozwój myśli dydaktycznej w polskiej literaturze katechetycznej w latach 18951970. Warszawa: Akademia Teologii Katolickiej, 1987.

Pawłowski, Zdzisław. Narracja i egzystencja. Genesis w hermeneutyce opowieści. Toruń: Wydawnictwo Naukowe UMK, 2013.

Przygotowanie do spowiedzi i Komunji św., oprac. Zygmunt Bielawski. Kraków: Nakładem Zgromadzenia ks. ks. Misjonarzy (Kleparz 19), 1922.

Scheidler, Monika. „Narracja biograficzna i narracja zorientowana na tradycję jako podstawowe formy nauczania katechetycznego". W: Narracyjny wymiar edukacji chrześcijańskiej, red. Anna Królikowska, 95-118. Kraków: Akademia Ignatianum, Wydawnictwo WAM, 2012.

Surma, Barbara. „Język biblijny - etapy wprowadzania dzieci do odczytywania znaków”. W: Język oknem na świat - edukacja językowa w pedagogice Marii Montessori, red. Małgorzata Miksza, 99-115. Łódź: Palatum, 2015.

Szymik, Stefan. „Metoda narracyjna jako propozycja dialogu z tekstem”. W: Język Biblii. Od słuchania do rozumienia, red. Wojciech Pikor, 11-20. Kielce: Verbum, 2005.

Trzebiński, Jerzy. „Autonarracje nadają kształt życiu ludzkiemu”. W: Narracja jako sposób rozumienia świata, red. Jerzy Trzebiński, 20-43. Gdańsk: GWP, 2002.

Witczyk Henryk. „Czytelnik jako współ-kreator postaci”. W: Język Biblii. Od słuchania do rozumienia, red. Wojciech Pikor, 70-89. Kielce: Verbum, 2005.

Żulińska, Barbara. Liturgia w ochronie. Rozmówki z małymi dziećmi. Katowice: Nakł. Księgarni św. Jacka w Katowicach, 1946.

Żulińska, Barbara. O wychowaniu religijnem dzieci w wieku przedszkolnym. Poznań-WarszawaWilno-Lublin: Nakład Księgarni św. Wojciecha, 1931. 